\title{
Molecular Analysis of the Pathogenesis of Autoimmune Insulitis in NOD Mice
}

\author{
Yukio Koide, Toshio Kaidoh, Moritaka Nakamura and \\ Takato O. Yoshida \\ Department of Microbiology/Immunology, Hamamatsu \\ University School of Medicine, Hamamatsu 431-31
}

\begin{abstract}
Koide, Y., Kaidoh, T., Nakamura, M. and Yoshida, T.O. Molecular Analysis of the Pathogenesis of Autoimmune Insulitis in NOD Mice. Tohoku J. Exp. Med., 1994, 173 (1), 157-170— Among diabetes-susceptibility genes in NOD mice, only $I d d-1$ has been clearly assigned: $I d d-1$ could be a gene complex composed of class II major histocompatibility complex (MHC) genes, $I-A \beta$ and $I-E$. Employing restriction fragment length polymorphism (RFLP) analysis and nucleotide sequencing, we revealed that ILI and CTS mice, which are nondiabetic but are derived from the same Jcl-ICR mice as NOD mice, share the same class II MHC genes with NOD mice, suggesting that both ILI and CTS mice also possess susceptible $I d d-1$ genotype. This was supported by a breeding study. To compare the usage of $\mathrm{T}$ cell receptor (TCR) $\mathrm{V} \beta$ genes in NOD mice with that in ILI mice, we employed quantitative reverse-transcriptase polymerase chain reaction (RT-PCR) which revealed that TCR $\mathrm{V} \beta$ usages of these mice were indistinguishable. RT-PCR method also revealed that the $\mathrm{V} \beta$ transcript of $\mathrm{T}$ cells infiltrating into pancreas of NOD mice was not restricted but was rather diverse. Since NOD and ILI mice share the same class I and II MHC antigens, we performed lymphocyte transfer experiments between these mice to examine the mechanism by which ILI mice do not develop insulitis. The results of reciprocal transfer of lymphocytes from NOD to ILI- $n u / n u$ mice or from ILI to young NOD mice suggest that ILI mice exhibit autoantigens responsible for the development of insulitis but do not possess $\mathrm{T}$ cells reacting with islets. Of the diabetessusceptibility genes, only in the case of $I d d-1$ is there any evidence for the identity of the gene products. ILI mice should provide more information on the products of the other diabetes-susceptibility genes of NOD mice.—— NOD mice; ILI mice; major histocompatibility complex (MHC); $\mathrm{V} \beta$ genes; insulitis
\end{abstract}

The nonobese diabetic (NOD) mouse spontaneously develops insulindependent diabetes mellitus (IDDM) with remarkable similarities to the human disorder (Makino et al. 1980). The onset of diabetes is preceded by autoimmune insulitis (Fujita et al. 1982; Kanazawa et al. 1984). In breeding studies, it has been revealed that at least three recessive genes on independent chromosomes, $I d d-1$ on chromosome $17, I d d-3$ on chromosome 3 , and $I d d-5$ on chromosome 1 , are responsible for the insulitis (Cornell et al. 1991; Garchon et al. 1991; Todd et al.

Address for reprints: Yukio Koide, Department of Microbiology/Immunology, Hamamatsu University School of Medicine, 3600 Handa-cho, Hamamatsu 431-31, Japan. 
1991). Among the genes, $I d d-1$ appeared to be located in the murine major histocompatibility complex (MHC). Therefore, we have investigated the MHClinked diabetogenic genes. First of all, we employed restriction fragment length polymorphism (RFLP) analyses to characterize the MHC genes of NOD mice in comparison with those of NON, CTS, and ILI mice which are non-diabetic inbred strains, but are derived from the same Jcl-ICR mice as NOD mice are (Yoshida et al. 1987).

We further analyzed the $\mathrm{T}$ cell receptor (TCR) $\mathrm{V} \beta$ usage of $\mathrm{T}$ cells infiltrating into the pancreas of NOD mice, since experimental allergic encephalomyelitis (EAE), one of best characterized autoimmune diseases, has been shown to be mediated by $\mathrm{T}$ cells bearing a limited heterogeneity of TCR (Acha-Orbea et al. 1988; Urban et al. 1988).

\section{RFLP analysis of $M H C$ genes}

The probes used for RFLP studies of class II MHC genes are shown in Fig. 1. Probe $1,2,3,4$, and 5, which were derived from the cosmid clones isolated from BALB/c or AKR DNA libraries (Steinmez et al. 1982a), pick up the $A \beta$, $A \alpha, E \beta$, and 5' and 3' portions of the $E_{\alpha}$ genes, respectively. Using these probes, mouse strains established from Jcl-ICR mice, NOD $\left(\mathrm{H}-2^{\mathrm{g} 7}\right)$, NON $\left(\mathrm{H}-2^{\mathrm{nb} 1}\right)$, CTS $\left(\mathrm{H}-2^{\mathrm{nc1}}\right)$, and ILI (H-2 $\left.{ }^{\mathrm{g} 7}\right)$, and two control strains, BALB/c $\left(\mathrm{H}-2^{\mathrm{d}}\right)$ and $\mathrm{C} 57 \mathrm{BL} / 6$ $\left(\mathrm{H}-2^{\mathrm{b}}\right)$, were analyzed for RFLP of class II genes. The results obtained by digesting genomic DNA with four restriction enzymes, EcoRI, BamHI, HindIII, and $K p n I$, are presented in Table 1 . With probe $1(\mathrm{~A} \beta)$, RFLP patterns of NOD, CTS, and ILI DNA were indistinguishable, but NON mice showed band patterns quite different from the other three ICR-derived mice with all four restiction enzymes. NOD, CTS, and ILI mice were different from BALB/c mice in digestion with HindIII and $K p n \mathrm{I}$, and were also different from $\mathrm{C} 57 \mathrm{BL} / 6$ mice in digestion with the all four enzymes.

With probe $2(A \alpha)$, HindII and $K p n I$ generated polymorphism. NOD, CTS,

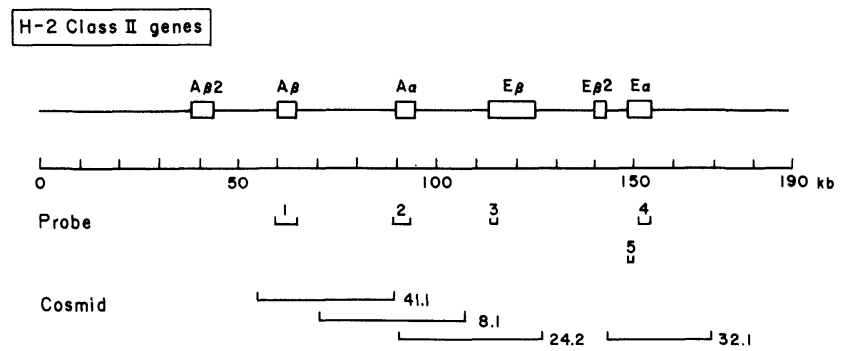

Fig. 1. Schematic map of the major histocompatibility complex (MHC) genes. Class II region and the hybridization probes used for restriction fragment length polymorphism (RFLP) analyses of class II genes are shown. These class II region cosmid clones were kindly provided by Dr. M. Steinmetz (Basel Institute for Immunology, Basel, Switzerland) 
TABLE 1. Results of restriction fragment length polymorphism analysis using class II major histocompatibility complex probes

\begin{tabular}{|c|c|c|c|c|c|c|c|c|c|c|c|}
\hline \multirow{2}{*}{$\begin{array}{c}\begin{array}{c}\text { Mouse } \\
\text { strain }\end{array} \\
\text { Probe } 1\end{array}$} & \multirow[t]{2}{*}{ H-2 } & \multicolumn{2}{|c|}{$E c o$ RI } & \multicolumn{2}{|c|}{ BamHI } & \multicolumn{4}{|c|}{ HindIII } & \multicolumn{2}{|c|}{$K p n \mathrm{I}$} \\
\hline & & & & & & & & & & & \\
\hline NOD & $\mathrm{g}$ & $6.6^{\mathrm{a}}$ & & 12.5 & 2.7 & & 6.4 & 5.5 & 1.9 & & 13 \\
\hline NON & $\mathrm{b}$ & 7.0 & & 9.6 & 2.7 & 2.3 & 8.2 & & & & $>30$ \\
\hline CTS & $?$ & 6.6 & & 12.5 & 2.7 & & 6.4 & 5.5 & 1.9 & & 13 \\
\hline ILI & $\mathrm{g}$ & 6.6 & & 12.5 & 2.7 & & 6.4 & 5.5 & 1.9 & & 13 \\
\hline $\mathrm{BALB} / \mathrm{c}$ & $\mathrm{d}$ & 6.6 & & 12.5 & 2.7 & & 6.4 & 2.8 & 1.9 & & $>30$ \\
\hline C57BL/6 & $\mathrm{b}$ & 7.0 & & 9.6 & 2.3 & & 8.2 & 4.7 & & & $>30$ \\
\hline \multicolumn{12}{|l|}{ Probe 2} \\
\hline NOD & $\mathrm{g}$ & 11.5 & & 6.0 & & & 11.0 & & & & 11.0 \\
\hline NON & $\mathrm{b}$ & 11.5 & & 6.0 & & & 6.1 & 2.7 & & & 15.0 \\
\hline CTS & $?$ & 11.5 & & 6.0 & & & 11.0 & & & & 11.0 \\
\hline ILI & $\mathrm{g}$ & 11.5 & & 6.0 & & & 11.0 & & & & 11.0 \\
\hline $\mathrm{BALB} / \mathrm{c}$ & d & 11.5 & & 6.0 & & & 11.0 & & & & 11.0 \\
\hline C57BL/6 & $\mathrm{b}$ & 11.5 & & 6.0 & & & 8.2 & 1.3 & & & 23.5 \\
\hline \multicolumn{12}{|l|}{ Probe 3} \\
\hline NOD & $\mathrm{g}$ & 2.1 & & 13.0 & & & 8.0 & & & & 23.5 \\
\hline NON & $\mathrm{b}$ & 2.1 & & 4.8 & & & 3.1 & & & & 15.0 \\
\hline CTS & $?$ & 2.1 & & 13.0 & & & 8.0 & & & & 23.5 \\
\hline ILI & $\mathrm{g}$ & 2.1 & & 13.0 & & & 8.0 & & & & 23.5 \\
\hline $\mathrm{BALB} / \mathrm{c}$ & $d$ & 1.9 & & 5.5 & & & 8.0 & & & & 15.0 \\
\hline C57BL/6 & $\mathrm{b}$ & 2.1 & & 13.0 & & & 8.0 & & & & 10.5 \\
\hline \multicolumn{12}{|l|}{ Probe 4} \\
\hline NOD & $\mathrm{g}$ & 8.4 & 3.0 & 7.4 & 7.0 & & 7.2 & & & 8.6 & 3.0 \\
\hline NON & $\mathrm{b}$ & 9.6 & 3.0 & 7.4 & & & 8.1 & & & 8.6 & 3.7 \\
\hline CTS & $?$ & 8.4 & 3.0 & 7.4 & 7.0 & & 7.2 & & & 8.6 & 3.0 \\
\hline ILI & $\mathrm{g}$ & 8.4 & 3.0 & 7.4 & 7.0 & & 7.2 & & & 8.6 & 3.0 \\
\hline $\mathrm{BALB} / \mathrm{c}$ & $\mathrm{d}$ & 9.6 & 3.0 & 7.4 & & & 8.1 & & & 8.6 & 3.7 \\
\hline C57BL/6 & $\mathrm{b}$ & 8.4 & 3.0 & 7.4 & 7.0 & & 7.2 & & & 8.6 & 3.0 \\
\hline \multicolumn{12}{|l|}{ Probe 5} \\
\hline NOD & $\mathrm{g}$ & 7.6 & & 5.6 & & & 8.6 & & & & 3.2 \\
\hline NON & $\mathrm{b}$ & 8.4 & & 6.2 & & & 9.0 & & & & 4.0 \\
\hline CTS & $?$ & 7.6 & & 5.6 & & & 8.6 & & & & 3.2 \\
\hline ILI & $\mathrm{g}$ & 7.6 & & 5.6 & & & 8.6 & & & & 3.2 \\
\hline $\mathrm{BALB} / \mathrm{c}$ & $d$ & 8.4 & & 6.2 & & & 9.0 & & & & 4.0 \\
\hline $\mathrm{C} 57 \mathrm{BL} / 6$ & $\mathrm{~b}$ & 7.6 & & 5.6 & & & 8.6 & & & & 3.2 \\
\hline
\end{tabular}

${ }^{\text {a }}$ Fragment sizes are in $\mathrm{kb}$ 
ILI, and BALB/c mice showed the same band patterns. However, NON mice showed distinct band patterns.

With probe $3\left(E_{\beta}\right)$, NOD, CTS, and ILI mice showed identical band patterns and NON mice exhibited distinct RFLP patterns. The same was true in the $E_{\alpha}$ gene where probe 4 and probe 5 picked up $5^{\prime}$ and $3^{\prime}$ portion of the $E_{\alpha}$ gene.

Taken together, these results indicate that the class II MHC genes of NOD mice are indistinguishable from those of CTS and ILI mice. However, the class II genes of NON mice are distinct from those of the other ICR-derived sister strains.

As shown in Fig. 2, a class I probe ( $5^{\prime}$ half of the coding region of the $L$ gene) detected many hybridized bands. This is due to the fact that the class I probe cross-hybridizes with not only the $\mathrm{K}$ and $\mathrm{D}$ genes but also the Qa genes (Steinmetz et al. 1982b). Therefore, we analyzed total hybridized bands obtained by digestion with the four restriction enzymes as percentage of coincidence of RFLP to NOD class I genes. The percent coincidence of RFLP to NOD class I DNA of

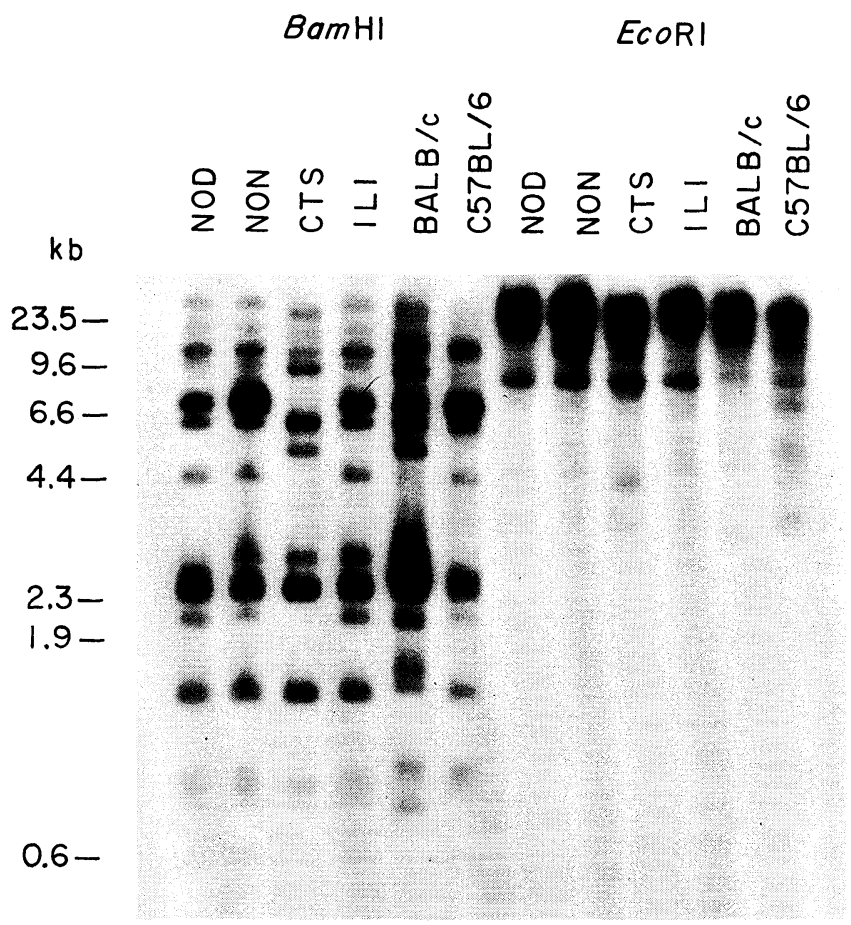

Fig. 2. Southern blot analysis of ICR-derived mice with class I probe L after digestion with $B a m \mathrm{HI}$ or $E c o$ RI. Ten $\mu \mathrm{g}$ of DNA were electrophoresed on $0.7 \%$ agarose gels, blotted, and hybridized with the probe. Sizes of DNA marker fragments are shown on the left of the figure. Probe $\mathrm{L}$ is a $X b a \mathrm{I}$ fragment from genomic clone $\mathrm{pL}^{\mathrm{d}}-4$ which was kindly provided by $\mathrm{Dr}$. T. Shiroishi (National Institute of Genetics, Mishima, Japan). 
NON, CTS, ILI, BALB/c, and C57BL/6 were approximately 88\%, 39\%, 90\%, $57 \%$, and $70 \%$, respectively. A summary of RFLP analyses using the class $\mathrm{I}$, class II, and class III probes, and a minimum of four restriction enzymes are schematically presented in Fig. 3. These results suggest that the class I genes of ILI mice bear a close resemblance to those of NOD mice and that the class I genes of CTS mice are quite different from those of NOD mice. This was supported by serological analyses. By serological typing, $\mathrm{H}-2 \mathrm{~K}$ and $\mathrm{H}-2 \mathrm{D}$ antigens of NOD mice appeared to be typed as $\mathrm{d}$ and $\mathrm{b}$, respectively. The haplotype is referred to $\mathrm{H}-2^{g 7}$ which is the same as that of ILI mice. Therefore, $10 \%$ difference of RFLP observed between NOD and ILI class I genes may be due to the difference of Qa gene polymorphism. CTS and NON mice showed unique $\mathrm{K}$ and $\mathrm{D}$ antigens (Ikegami et al. 1988). Taken together, these results indicate that ILI mice share the same class I K, D and class II antigens with NOD mice.

\section{The nucleotide sequence of the A gene}

Acha-Orbea and McDevitt (1987) reported that I-A $\beta$ amino acid sequence of NOD mice differs from those of all characterized murine strains at residues 56 (Pro $\rightarrow \mathrm{His})$ and $57(\mathrm{Asp} \rightarrow \mathrm{Ser})$. It is, therefore, conceivable that the unique sequence of the I-A $\beta$ may contribute to the development of diabetes. Substitution of a non-charged amino acid with a charged amino acid at residue 56 or a charged amino acid with a non-charged amino acid at residue 57 may affect the conformation of the class II molecule or the binding of peptides processed from a putative diabetes autoantigen. This idea was supported by the recent transgenic mouse experiments and the analysis of human IDDM patients. Transgenic NOD mice expressing a modified I-A $\beta$ encoding Pro instead of His at residue 56 were reported to be protected from insulitis (Lund et al. 1990). Furthermore, in the Caucasian IDDM patients, substitutions of Asp57 with non-Asp57 were observed in the DQ $\beta$ chain which is the human homolog of the $A \beta$ chain (Todd et al. 1987).

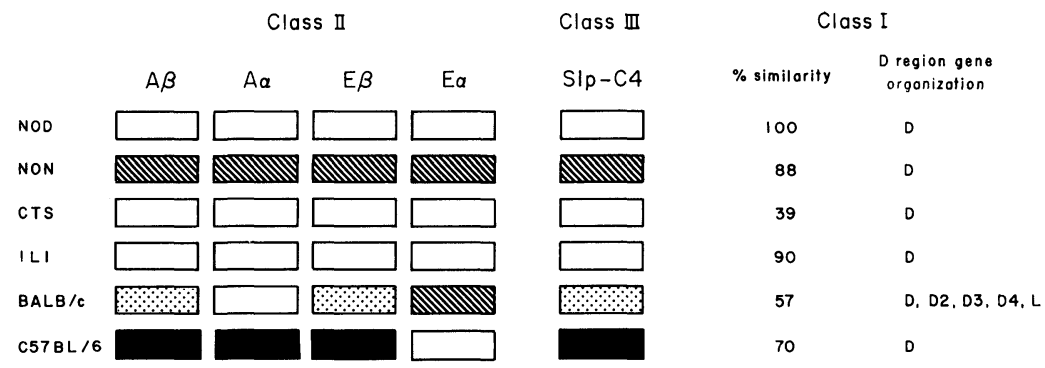

Fig. 3. Summary of restriction fragment length polymorphism (RFLP) analyses of MHC genes of class I, II, and III regions in NOD, NON, CTS, and ILI mice. Open boxes ( $\square$ ): RFLP patterns unique for NOD mice; oblique lined boxes (\$): RFLP patterns unique for NON mice; dotted boxes (\$): RFLP patterns unique for BALB/c mice; closed boxes ( $\square$ ): RFLP patterns unique for $\mathrm{C} 57 \mathrm{BL} / 6$ mice. 
Our nucleotide sequence studies (Fig. 4) indicate that ILI and CTS mice share the unique I-A $\beta$ sequence with NOD mice. However, NON mice showed a sequence quite different from these mice.

\section{Class II MHC gene expression}

NOD and NON mice were examined for class II gene expression. Northern blot analyses indicated that both NOD and NON mice express $\mathrm{A} \alpha, \mathrm{A} \beta$, and $\mathrm{E} \beta$ mRNA (Fig. 5). Although NON mice express $\mathrm{E} \alpha$ mRNA, NOD mice failed to express the $E_{\alpha}$ gene. We have, therefore, investigated the molecular mechanisms by which this defect is generated. As shown in Table 1, RFLP analysis suggests that the $E \alpha$ gene of NOD mice is indistinguishable from that of C57BL/6 mice

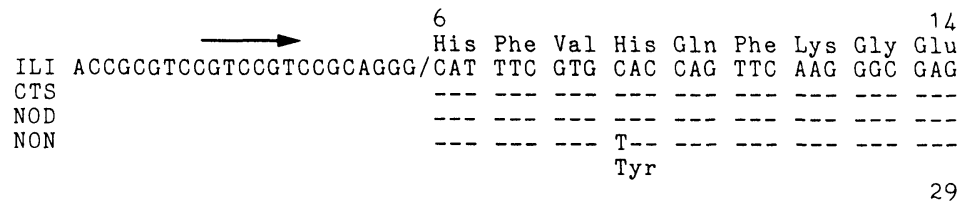

Cys Tyr Phe Thr Asn Gly Thr Gln Arg Ile Arg Leu Val Thr Arg ILI TGC TAC TTC ACC AAC GGG ACG CAG CGC ATA CGG CTC GTG ACC AGA CTS - - - - - - - _-

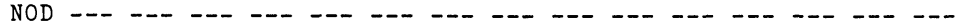

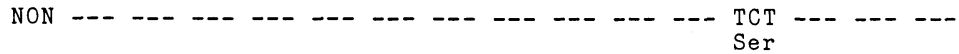

Tyr Ile Tyr Asn Arg Glu Glu Tyr Leu Arg Phe Asp Ser Asp Val ILI TAC ATC TAC AAC CGG GAG GAG TAC CTG CGC TTC GAC AGC GAC GTG CTS -. _.. _.. _.. _.

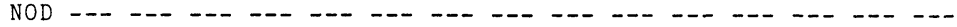

NON A-- $\begin{aligned} & \text { Asn } \\ & \text { Asn }\end{aligned}$

Gly Glu Tyr Arg Ala Valo 59 ILI GGC GAG TAC CGC GCG GTG ACC GAG CTG GGG CGG CAC TCA GCC GAG CTS -- - - - NON - - -

Tyr Tyr Asn Lys GIn Tyr Leu Glu Ar Thr Arg Alo Glu LeU A 74 ILI TAC TAC AAT AAG CAG TAC CTG GAG CGA ACG CGG GCC GAG CTG GAC

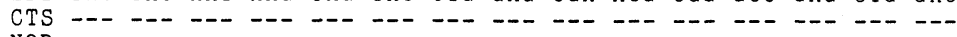

NOD -.- - -

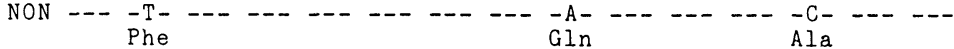

Thr Ala Cys Arg His Asn Tyr Glu Glu Thr Glu Val Pro Thr Ser ILI ACG GCG TGC AGA CAC AAC TAC GAG GAG ACG GAG GTC CCC ACC TCC

CTS -

NOD

NON -- - Val Gly Val Thr Ser

Leu Arg Arg Leu

ILI CTG CGG CGG CTT G/GTGAGCGCGGCGGGTCCCGCGGGA

CTS -- --- -- -- -

NOD -- - - - - - - -

NON $--1-2-1-2-$

Fig. 4. Aligned nucleotide and translated amino acid sequences of I-A $\beta$ in the ILI, CTS, NOD, and NON mice. The arrows indicate primers used for PCR. Dashed lines indicate identity with ILI sequence. The amino acid numbering starts with the first amino acid of the first external domain. Amino acids at position 57 are boxed. 


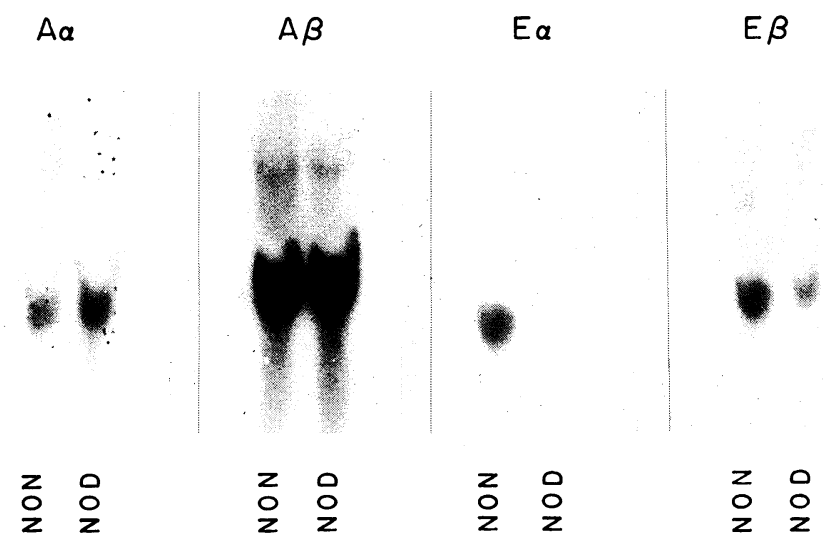

Fig. 5. Northern blot analysis of $A \alpha, A \beta, E \alpha$, and $E \beta$ transcripts in NOD and NON mice. Twenty $\mu \mathrm{g}$ of total RNA per lane were electrophoresed on $1 \%$ agarose formaldehyde gels, blotted, and hybridized with class II probes.

$\left(\mathrm{H}-2^{\mathrm{b}}\right)$. Mice of haplotypes $\mathrm{b}$ and $\mathrm{s}$ bear a deletion spanning $627 \mathrm{bp}$ which includes the promoter region and the signal peptide exon of the $E_{\alpha}$ gene. Therefore, we prepared probe 6 , which is deleted in C57BL/6 mice, from a cosmid of BALB/c mice (Fig. 6). As shown in Fig. 7, probe 6 hybridized with a $4.0 \mathrm{~kb}$ $K p n I$ fragment in NON and BALB/c mice. However, no hybridized band was observed in NOD, CTS, ILI, and C57BL/6 mice, suggesting that NOD, CTS, and ILI mice bear the same deletion as mice of haplotypes $b$ and $s$ do. This mutation must prevent transcription of the $E \alpha$ gene in these mice.

\section{ILI mice possess MHC-linked diabetes susceptibility gene, Idd-1}

Transgenic mouse experiments suggest that MHC-linked diabetes susceptibility gene, Idd-1, could be a gene complex composed of at least two susceptibility loci, which are unique $I-A \beta$ gene $\left(I-A \beta^{87}\right)$ and a defect of the $E \alpha$ gene (Nishimoto et al. 1987; Lund et al. 1990; Miyazaki et al. 1990; Slattery et al. 1990). From our data, it is most likely that both ILI mice and CTS mice possess the Idd-1.

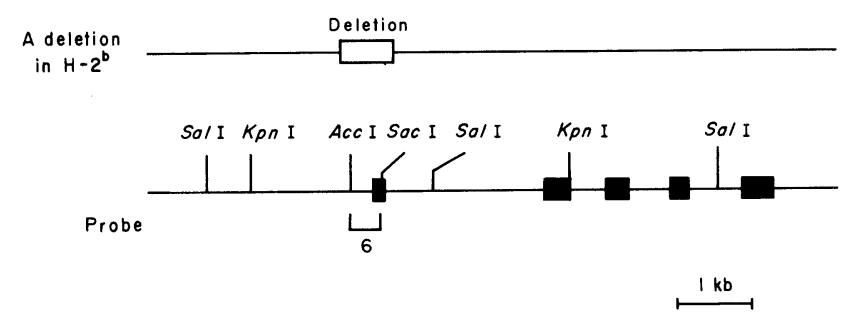

Fig. 6. Probe 6 (0.4 kb AccI-SacI fragment from cosmid clone 32.1) corresponds to the fragment spanning the promoter region and the signal peptide exon of the $E_{\alpha}$ gene. 


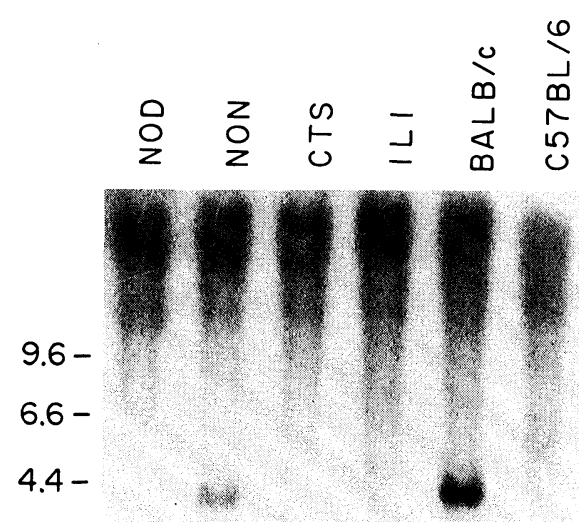

Fig. 7. Southern blot analysis of ICR-derived mice with probe 6 after digestion with $K p n I$. Sizes of DNA marker fragments are shown at the left of the figure.

TABLE 2. Incidence of insulitis in NOD, ILI, theIR $F_{1}$ and backcross mice

\begin{tabular}{|c|c|c|}
\hline Strain \& progenies & $\begin{array}{c}\text { Sex \& } \\
\text { number of mice }\end{array}$ & $\begin{array}{c}\text { Percentage of } \\
\text { insulitis-positive mice }\end{array}$ \\
\hline NOD & $\begin{array}{l}\text { M (38) } \\
\text { F (51) }\end{array}$ & $\begin{array}{l}94.7 \\
96.1\end{array}$ \\
\hline ILI & $\begin{array}{l}\text { M (16) } \\
\text { F (13) }\end{array}$ & $\begin{array}{l}0 \\
0\end{array}$ \\
\hline$(\mathrm{ILI} \times \mathrm{NOD}) \mathrm{F}_{1}$ & $\begin{array}{l}\text { M }(34) \\
\text { F }(42)\end{array}$ & $\begin{array}{r}2.9 \\
<2.3\end{array}$ \\
\hline $\mathrm{NOD} \times(\mathrm{ILI} \times \mathrm{NOD}) \mathrm{F}_{1}$ & $\begin{array}{l}\text { M (44) } \\
\text { F (39) }\end{array}$ & $\begin{array}{l}54.5 \\
71.8\end{array}$ \\
\hline $\mathrm{ILI} \times(\mathrm{ILI} \times \mathrm{NOD}) \mathrm{F}_{1}$ & $\begin{array}{l}\text { M (28) } \\
\text { F (21) }\end{array}$ & $\begin{array}{l}0 \\
0\end{array}$ \\
\hline
\end{tabular}


TABLE 3. Linkage between insulitis and class $I$ $M H C$ locus in $N O D \times(I L I \times N O D) F_{1}$ mice

\begin{tabular}{|c|c|c|}
\hline \multirow{2}{*}{ Insulitis } & \multicolumn{2}{|c|}{$\mathrm{MHC}$} \\
\hline & NOD type & $\mathrm{F}_{1}$ type \\
\hline+ & 8 & 2 \\
\hline- & 6 & 1 \\
\hline
\end{tabular}

This possibility was examined by breeding studies. Table 2 shows that, in NOD mice, $94.7 \%$ of male and $96.1 \%$ of female mice developed insulitis at 4 months of age. There was no significant difference in the incidence between male and female mice. ILI mice showed no insulitis and a small percentage of (ILI $\times$ $\mathrm{NOD}) \mathrm{F}_{1}$ mice developed insulitis. $\mathrm{NOD} \times(\mathrm{ILI} \times \mathrm{NOD}) \mathrm{F}_{1}$ backcross mice generated $63 \%$ insulitis-positive mice. However, reciprocal $\mathrm{ILI} \times(\mathrm{ILI} \times \mathrm{NOD}) \mathrm{F}_{1}$ mice generated no insulitis-positive mouse. These data indicate that one recessive gene is responsible for the difference in the incidence of insulitis between NOD and ILI mice. We also examined the linkage between $\mathrm{MHC}$ and insulitis in $\mathrm{NOD} \times(\mathrm{ILI} \times \mathrm{NOD}) \mathrm{F}_{1}$ mice as shown in Table 3 . The class $\mathrm{I}$ MHC gene derived from ILI is recognized by one SacI digested band by Southern blotting. Recombination rate observed between $\mathrm{MHC}$ and insulitis was 0.47 , suggesting that one recessive insulitis-susceptibility gene, which is absent in ILI mice, is not linked to MHC. These data suggest that ILI mice already possess at least one MHC-linked insulitis susceptibility gene, Idd-1.

TCR V $\beta$ gene usages in spleen cells from NOD and ILI mice, and $T$ cells infiltrating into pancreata of NOD mice

To investigate whether the induction of insulitis is influenced by the difference of TCR V $\beta$ usages, we compared TCR V $\beta$ usages of NOD mice with that of ILI mice, which share the same MHC antigens. For this purpose, we employed quantitative reverse-transcriptase (RT)-PCR method (Koide et al. 1992). We extracted total RNA from spleen cells and synthesized single strand cDNA. Using various $5^{\prime} V \beta$ primers and a ${ }^{32} \mathrm{P}$-labeled $3^{\prime} C \beta$ primer, the cDNA was amplified by PCR. As shown in Table 4, primers PMB1 to PMB19 have sequences identical to the corresponding $V \beta 1$ to $V \beta 19$ genes. $5^{\prime} C \alpha$ and $3^{\prime} C \alpha$ primers were used as controls. The amplified products were separated on a $8 \%$ acrylamide gel, dried, and exposed to x-ray film. The $V \beta-C \beta$ bands were excised and assayed for radioactivity by liquid scintillation spectroscopy. Quantification of PCR products was performed by a formula described by Chelly et al. (1988). As shown in Fig. 8, where the percentage was mean of three 
TABLE 4. Sequences of primers for PCR

\begin{tabular}{lcll}
\hline File name & \multicolumn{3}{c}{ Sequence } \\
\hline & \multicolumn{2}{c}{10} & \\
PMVB1 & ACAGTTGATT & CGAAATGAGA & CGG \\
PMVB2 & AGTCCTGGGG & ACAAAGAGGT & CAAA \\
PMVB3 & CTTTCAGAAT & CAAGAAGTTC & TTC \\
PMVB4 & TTATGGACAA & TCAGACTGCC & TC \\
PMVB5 & GGAGAGAGAT & AAAGGAAACC & \\
PMVB6 & AAAGGCGATC & TATCTGAAGG & CTAT \\
PMVB7 & TAGTAACAGC & GAAGGAGACA & TCCC \\
PMVB8 & ACAGGAGGAA & ACGTGACATT & GAGC \\
PMVB9 & GATTTTGAAC & AGGGAAGCTG & ATACT \\
PMVB10 & GCTTCTCACC & TCAGTCTTCA & GAT \\
PMVB11 & TCCTATAGAT & GATTCAGGGA & TGCC \\
PMVB12 & TTATGGAAGA & TGGTGGGGAT & \\
PMVB13 & TGCCCTCGGA & TCGATTTTCT & GCTG \\
PMVB14 & ATTACTGTTG & GCCAGGTAGA & GT \\
PMVB15 & GGCATTTGAA & CTGATAGCAC & \\
PMVB16 & GGTAAAGTCA & TGGAGAAGTC & T \\
PMVB17 & GGAACAAACA & GACTTGGTCA & AGAA \\
PMVB18 & CGGCCAAACC & TAACATTCTC & AACGT \\
PMVB19 & CCCATAAACG & GACATAGTTA & CG \\
MO3CB & GTGGAGTCAC & ATTTCTCAGA & TCC \\
MO5CA & AGAACCTGCT & GTGTACCAGT & TA \\
MO3CA & AGCTCTCTAG & CAACCTTCCT & CACA \\
\hline
\end{tabular}

$\mathrm{PMVB1} \sim \mathrm{PMVB} 19$ are $5^{\prime}$ primers specific for mouse $\mathrm{V} \beta 1$ $\sim \mathrm{V} \beta 19$ genes. $\mathrm{MO} 3 \mathrm{CB}$ is 3 primer specific for mouse $\mathrm{C} \beta 1$ and 2 genes. MO5CA and MO3CA are used for $5^{\prime}$ primer and $3^{\prime}$ primer of $\mathrm{C} \alpha$, respectively.

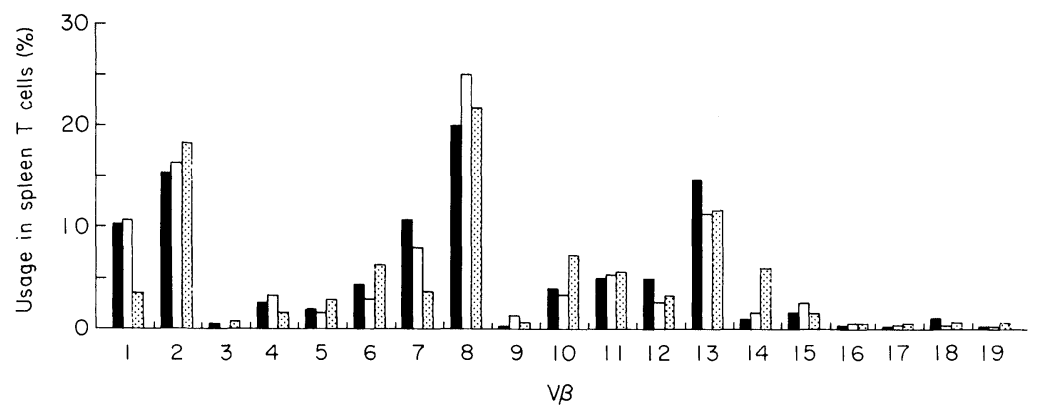

Fig. 8. $V \beta$ gene expression in spleen cells of NOD, ILI, and their $\mathrm{F}_{1}$ mice. The percentage of $\mathrm{T}$ cells bearing each $V \beta$ was calculated by the normalized cpm in the $V \beta$ band to those in the $E \alpha$ band.

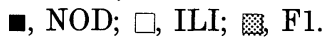



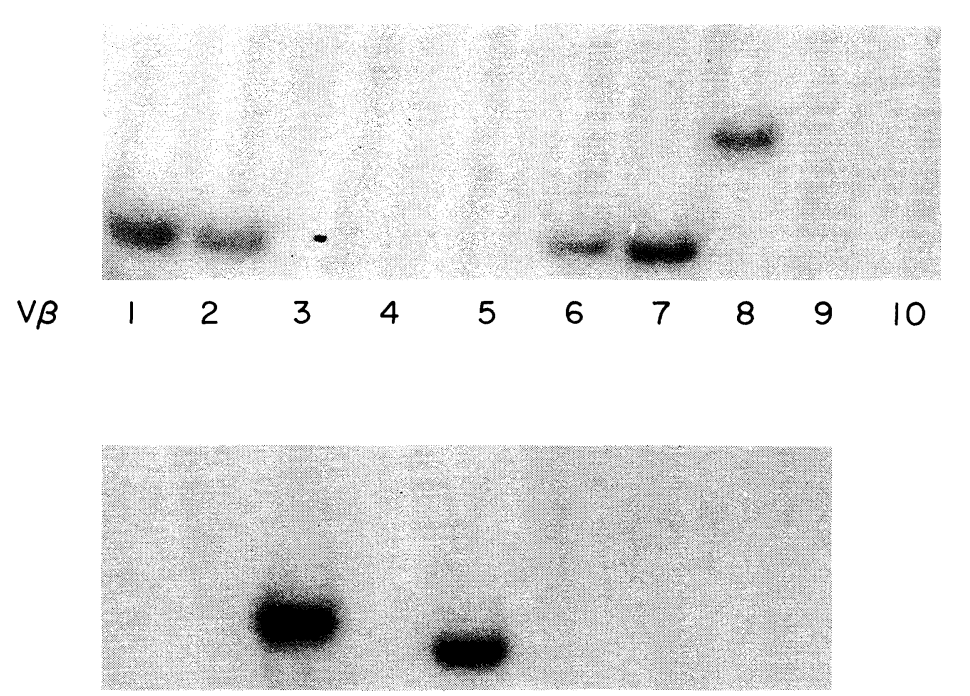

$\begin{array}{llllllllll}V \beta & 11 & 12 & 13 & 14 & 15 & 16 & 17 & 18 & 19\end{array}$

Fig. 9. Autoradiogram of amplified cDNA of $V \beta$ transcripts from $\mathrm{T}$ cells infiltrating into the pancreas of NOD mice. Amplified products were electrophoresed on $8 \%$ acrylamide gels, dried, and exposed to $\mathrm{x}$-ray film with an intensifying screen.

independent experiments, no obvious difference was evident in the $V \beta$ gene usage of NOD, ILI, and $(\mathrm{ILI} \times \mathrm{NOD}) \mathrm{F}_{1}$ mice.

We further analyzed the TCR $V \beta$ usage of infiltrating T cells within islets of NOD mice. Total RNA isolated from infiltrating $T$ cells within islets of 8-20 week-old male NOD mice was used to synthesize cDNA. The cDNA was then subjected to enzymatic gene amplification by PCR. Fig. 9 shows that the $V \beta 1$, $2,6,8,13$, and 15 were expressed by the infiltrating $\mathrm{T}$ cells. The usage of $\mathrm{V} \beta$ gene segments was not restricted but was rather diverse. Recently, Nakano et al. (1991) established 5 islet-reactive $\mathrm{T}$ cell clones from pancreatic islet-infiltrating cells of NOD mice. In consistent with our observation, their usages of TCR V and $\mathrm{J}$ segments were not restricted.

ILI mice do not possess diabetogenic $T$ cells but present autoantigens resposible for insulitis

Since no obvious difference of the MHC genes and $\mathrm{V} \beta$ usage was observed between NOD and ILI mice, we further investigated whether ILI mice do not possess diabetogenic $\mathrm{T}$ cells or do not present autoantigens responsible for insulitis. Transfer of spleen cells from diabetic NOD mice to BALB/c-nu/nu mice could not elicit IDDM (Table 5). However, the same transfer to ILI nude (M3) mice via i.p. or i.v. route induced IDDM. Conversely, the transfer of spleen cells from ILI mice (3-5 months) to young NOD mice (4-5 days) could not accelerate 
TABLE 5. IDDM induced in ILI-nu/nu (M3) by transfer of NOD splenic lymphocytes

\begin{tabular}{ccccc}
\hline Mice & Sex & Lymphocytes & & Oncet of IDDM \\
\hline BALB/c- $n u / n u$ & F & $6.0 \times 10^{6}$ & i.v. & $0 / 2$ \\
ILI- $n u / n u$ & F & $6.0 \times 10^{6}$ & i.v. & $2 / 2$ \\
& M & $2.6 \times 10^{7}$ & i.p. & $2 / 5$ \\
& M & $5.0 \times 10^{7}$ & i.p. & $2 / 2$ \\
\hline
\end{tabular}

TABLE 6. Factors required for the development of insulitis

1. The repertoire of T-cell receptor

i) $\mathrm{MHC}$

$\mathrm{I}-\mathrm{A} \beta^{\mathrm{NOD}}, \mathrm{I}-\mathrm{E}^{\mathrm{O}}$

ii) Non-MHC molecules

2. Expression of target molecules

Antigen-presenting cells

3. Costimulators

i) Without costimulators .........Paralysis

ii) IL-1

iii) $\mathrm{B} 7 \quad \ldots \ldots \ldots \mathrm{T}_{\mathrm{H} 1}$

the development of insulitis and diabetes (data not shown). These date suggest that ILI mice exhibit autoantigens responsible for the development of insulitis but do not possess $\mathrm{T}$ cells reacting with the islets.

\section{Concluding remarks}

At least three factors seem to be required for the development of insulitis in NOD mice (Table 6). The first factor is the formation of $\mathrm{T}$ cell repertoire. $\mathrm{T}$ cell repertoire is selected by MHC plus non-MHC antigens (Blackman et al. 1990). Our data suggest that NOD and ILI mice share the same class I and II MHC antigens. It is, however, possible that $\mathrm{T}$ cell repertoires are still different between NOD and ILI mice. The second factor is autoantigens responsible for the development of insulitis, which appears to be present in ILI mice as well as in NOD mice. The third factor is a costimulating factor. It has been demonstrated that, without costimulators, $\mathrm{T}$ cells would result in paralysis (Weaver and Unaue 1990). The same antigen stimulation induces either IL-1 or B7 as a costimulator depending on the murine strain used. It is well-known that IL-1 induces Th2, whereas B7 induces Th1 (Reiser et al. 1992). Therefore, whether IL-1 or B7 is induced is critical for the quality of immune response.

Our data suggest that costimulators, non-MHC molecules in the thymus which bind to MHC molecules, or T-T cell interactions including suppressor T cells could be responsible for the development of insulitis in ILI mice. 
Of the diabetes-susceptibility genes, only in the case of $I d d-1$ is there any evidence for the identity of the gene products. ILI mice should provide more information on the products of the other diabetes-susceptibility genes of NOD mice.

\section{References}

1) Acha-Orbea, H. \& McDevitt, H.O. (1987) The first external domain of the nonobese diabetic mouse class II I-A $\beta$ chain is unique. Proc. Natl. Acad. Sci. USA, 84, 24352439.

2) Acha-Orbea, H., Mitchell, D.J., Timmermann, L., Wairth, D.C., Tauch, G.S., Waldor, M.K., Zamvil, S.S., McDevitt, H.O. \& Steinmann, L. (1988) Limited heterogeneity of $\mathrm{T}$ cell receptors from $\mathrm{T}$ lymphocytes mediating autoimmune encephalomyelitis allows specific immune intervention. Cell, 54, 263-273.

3) Blackman, M., Kappler, J. \& Marrack, P. (1990) The role of the T cell receptor in positive and negative selection of developing T cells. Science, 248, 1335-1341.

4) Chelly, J., Kplan, J-C., Maire, P., Gautron, S. \& Kahn, A. (1988) Transcription of the dystrophin gene in human muscle and non-muscle tissue. Nature, 333, 858-860.

5) Cornall, R.J., Prins, J.-B., Todd, J.A., Pressey, A., Delarato, N.H., Wickey, L.S. \& Peterson, L.B. (1991) Type I diabetes in mice is linked to the interleukin-1 receptor and Lsh/Ity/Bcg genes on chromosome 1. Nature, 353, 262-265.

6) Fujita, T., Yui, R., Kusumoto, Y., Serizawa, Y., Makino, S. \& Tochino, Y. (1982) Lymphocytic insulitis in a "non-obese diabetic (NOD)" strain of mice: An immunohistochemical and electron microscope investigation. Biomed: Res., 3, 429-443.

7) Garchon, H.J., Bedossa, P., Eloy, L. \& Bach, J.-F. (1991) Identification and mapping to chromosome 1 of a susceptibility locus for periinsulitis in non-obese diabetic mice. Nature, 353, 260-262.

8) Ikegami, H., Makino, S., Harada, M., Eisenbarth, G.S. \& Hattori, M. (1988) The cataract Shionogi mouse, a sister strain of the non-obese diabetic mouse: Similar class II but different class I gene products. Diabetologia, 31, 254-258.

9) Kanazawa, Y., Komeda, K., Sato, S., Mori, R., Akanuma, Y. \& Takaku, F. (1984) Non-obese-diabetic mice: Immune mechanisms of pancreatic B-cell destruction. Diabetologia, 27, 113-115.

10) Koide, Y., Fujishima, Y., Kaidoh, T., Yanagawa, T., Matsuyama, S. \& Yoshida, T.O. (1992) Molecular analyses of $\mathrm{MHC}$ genes and the usage of $\mathrm{T}$ cell receptor $\mathrm{V} \beta$ genes in the NOD mouse and its nondiabetic sister strains. In: Molecular Approaches to the Study and Treatment of Human Diseases, edited by T.O. Yoshida \& J.M. Wilson, Elsevier Science Publishers B.V., The Netherlands, pp. 323-337.

11) Lund, T., O'Reilly, L., Hutchings, P., Kanagawa, O., Simpson, E., Gravely, R., Chandler, P., Dyson, J., Picard, J.K., Edwards, A., Kioussis, D. \& Cooke, A. (1990) Prevention of insulin-dependent diabetes mellius in non-obese diabetic mice by transgenes encoding modified I-A $\beta$-chain or normal I-E $\alpha$-chain. Nature, 345, 727729 .

12) Makino, S., Kunimoto, K., Muraoka, Y., Mizushima, Y., Katagiri, K. \& Tochino, Y. (1980) Breeding of a non-obese, diabetic strain of mice. Exp. Animal (Tokyo), 29, $1-13$.

13) Miyazaki, T., Uno, M., Uehira, M., Kikutani, H., Kishimoto, T., Kimoto, M., Nishimoto, H., Miyazaki, J. \& Yamamura, K. (1990) Direct evidence for the contribution of the unique I-A $\mathrm{A}^{\mathrm{NOD}}$ to the development of insulitis in non-obese diabetic mice. Nature, 345, 722-724.

14) Nakano, N., Kikutani, H., Nishimoto, H. \& Kishimoto, T. (1991) T cell receptor V gene usage of islet $\beta$ cell-reactive $\mathrm{T}$ cells is not restricted in non-obese diabetic mice. 
J. Exp. Med., 173, 1091-1097.

15) Nishimoto, H., Kikutani, H., Yamamura, K. \& Kishimoto, T. (1987) Prevention of autoimmune insulitis by expression of I-E molecules in NOD mice. Nature, 328, 432 434.

16) Reiser, H., Freeman, G.J., Razi-Wolf, Z., Gimmi, C.D., Benacerraf, B. \& Nadler, L.M. (1992) Murine B7 antigen provides an efficient costimuratory signal for activation of murine T lymphocytes via T-cell receptor/CD3 complex. Proc. Natl. Acad. Sci. USA, 89, 271-275.

17) Slattery, R.M., Kjer-Nielsen, L., Allison, J., Charlton, B., Mandel, T.E. \& Miller, J.F.P. (1990) Prevention of diabetes in non-obese diabetic I-A ${ }^{\mathrm{k}}$ transgenic mice. Nature, 345, 724-726.

18) Steinmetz, M., Minard, K., Horvath, S., McNicholas, J., Srelinger, J., Wake, C., Long, E., Mach, B. \& Hood, L. (1982a) A molecular map of the immuoe response region from the major histocompatibility complex of the mouse. Nature, 300, 35-42.

19) Steinmetz, M., Winoto, A., Minard, K. \& Hood, L. (1982b) Clusters of genes encoding mouse transplantation antigens. Cell, 28, 489-498.

20) Todd, J.A., Bell, J.I. \& McDevitt, H.O. (1987) HLA-DQ $\beta$ gene contributes to susceptibility and resistance to insulin-dependent diabetes mellitus. Nature, 329, 599-604.

21) Todd, J.A., Aitman, T.J., Cronall, R.J., Ghosh, S., Hall, J.R.S., Hearne, C.M., Knight, A.M., Love, J.M., McAller, M.A., Prins, J.-B., Rodrigues, N., Lathrop, M., Pressey, A., DeLarato, N.H., Peterson, L.B. \& Wicker, L.S. (1991) Genetic analysis of autoimmune type I diabetes mellitus in mice. Nature, 351, 542-527.

22) Urban, J., Kumar, V., Kono, D.H., Gomerz, C., Horvah, S.J., Clayton, J., Ando, D.G., Sercarz, E.E. \& Hood, L. (1988) Restricted use of T cell receptor V gene in murine autoimmune encephalomyelitis raises possibility to antibody therapy. Cell, 54, 577592.

23) Weaver, C.T. \& Unaue, E.R. (1990) The costimulatory function of antigen presenting cells. Immunol. Today, 11, 49-55.

24) Yoshida, T.O., Koide, Y., Fujishima, Y., Hori, T., Masamoto, T., Wu, C.L., Haraguchi, S. \& Nishimura, M. (1987) Gene modification and autoimmune mechanisms in NOD mouse strain as human IDDM model. In: New Horizons in Animal Models for Autoimmune Diseases, edited by H. Wigzell \& M. Kyogoku, Academic Press, Tokyo, pp. 59-67. 